\title{
Sodium salicylate treatment in early lactation increases whole-lactation milk and milk fat yield in mature dairy cows
}

\author{
J. K. Farney, ${ }^{*}$ L. K. Mamedova, ${ }^{*}$ J. F. Coetzee,† J. E. Minton, ${ }^{*}$ L. C. Hollis, ${ }^{*}$ and B. J. Bradford ${ }^{* 1}$ \\ ${ }^{*}$ Department of Animal Sciences and Industry, Kansas State University, Manhattan 66506 \\ †Veterinary Diagnostic and Production Animal Medicine Department, lowa State University, Ames 50011
}

\begin{abstract}
Multiple lines of inquiry have suggested that a high degree of inflammation in early lactation cows is associated with low productivity and increased disease incidence. In addition, some small studies have suggested that milk production increases in response to antiinflammatory treatment in the first week of lactation. Our objective was to determine if administration of sodium salicylate (SS), a nonsteroidal antiinflammatory drug (NSAID), in the first week of lactation changes whole-lactation productivity and retention in the herd. At calving, 78 cows $[\mathrm{n}=39$ primiparous $(1 \mathrm{P}) ; \mathrm{n}=24$ second parity $(2 \mathrm{P}) ; \mathrm{n}=15$ third parity or greater $(3 \mathrm{P})]$ were alternately assigned to either control (CON) or SS treatments for $7 \mathrm{~d}$ postpartum. Sodium salicylate treatment was administered via individual water bowls at a concentration of $1.95 \mathrm{~g} / \mathrm{L}$, delivering a mean of $123.3 \pm 5.5 \mathrm{~g}$ of salicylate/d during the 7 -d treatment. For the first $21 \mathrm{~d}$ of lactation, dry matter intake, water intake, milk yield, and health were monitored daily, and milk samples were collected twice weekly for milk component analysis. Monthly milk yield and component testing through the rest of the lactation provided data to assess long-term responses, and the effects of treatment on the risk of leaving the herd and on 305-d milk, fat, and protein yields were assessed. During the first $21 \mathrm{~d}$ of lactation, we observed no differences in morbidity, except for increased risk of metritis in $3 \mathrm{P}$ SS cows. Treatment interacted with parity to influence both 305-d milk and milk fat yields, and a tendency for an interaction was detected for 305-d milk protein yield. Milk yield was 2,469 $\pm 646 \mathrm{~kg}$ greater over the lactation in $3 \mathrm{P}$ SS cows compared with $3 \mathrm{P}$ CON cows (21\% increase) and tended to decrease by $8 \%$ in $1 \mathrm{P}$ cows treated with SS; no effects were detected in $2 \mathrm{P}$ cows. Furthermore, 3P SS cows produced $130 \pm 23 \mathrm{~kg}$ more milk fat over the lactation (30\% increase), with no effects detected for $1 \mathrm{P}$ or $2 \mathrm{P}$. Treatment with SS
\end{abstract}

Received May 31, 2013.

Accepted September 1, 2013.

${ }^{1}$ Corresponding author: bbradfor@ksu.edu tended to increase 305-d milk protein yield in $3 \mathrm{P}$ cows by $14 \%$, with no effects in $1 \mathrm{P}$ or $2 \mathrm{P}$ cows. A tendency for a treatment $\times$ parity interaction was also observed for the risk of leaving the herd. First-parity cows treated with SS tended to have greater risk of leaving the herd than controls (30 vs. $6 \%$ risk); however, treatment did not alter herd retention in $2 \mathrm{P}$ or $3 \mathrm{P}$ groups, and SS had no effect on the risk of leaving the herd overall. Results indicate that SS has long-term effects on lactation of mature dairy cows, particularly on fat yield, but may have negative effects for primiparous cows.

Key words: nonsteroidal antiinflammatory drug, inflammation, programming

\section{INTRODUCTION}

The presence of an inflammatory state in postpartum dairy cows is well established. Although early studies focused on associations between inflammatory markers and diseases such as mastitis and metritis, numerous studies in the past decade have demonstrated that inflammatory and acute-phase mediators are elevated in the days after parturition, even in cows that are apparently healthy (Humblet et al., 2006; Bionaz et al., 2007; Huzzey et al., 2009; Graugnard et al., 2012; Mullins et al., 2012). This growing body of evidence suggests that either the processes of parturition and galactopoiesis induce inflammation directly or that infections or endotoxin affect far more postpartum cows than is currently recognized. Whatever the explanation, the prevalence of postpartum inflammation raises important questions about the implications of this inflammation across numerous organs.

Although most transition dairy cows apparently experience a period of inflammation, the magnitude of this inflammatory condition varies greatly between cows. Bertoni et al. (2008) assessed the importance of this variation by measuring a panel of inflammatory markers and separating transition cows into quartiles for degree of inflammation. Cows in the highest quartile had significantly lower milk yields than those in the lowest quartile throughout the first month of lactation, differing by $20 \%$ on d 28 of lactation (Bertoni et al., 
2008). One metric that has been used in this respect is paraoxanase, a plasma biomarker that is potently suppressed by a variety of inflammatory stimuli. Transition cows with high paraoxanase concentrations, in addition to having lower concentrations of acute phase proteins and reactive oxygen metabolites, produced $1,971 \mathrm{~kg}$ more milk (24\%) over $305 \mathrm{~d}$ than did those in the lowest quartile for paraoxanase (Bionaz et al., 2007).

It is possible that these studies identified cows with primary inflammatory conditions that impaired milk production capacity, but it is also possible that the primary issue in these cows was a health disorder (e.g., metritis, displaced abomasum) that was the causative factor underlying both inflammation and the decrease in milk production (Ingvartsen, 2006). Experimental strategies to alter endogenous inflammation in apparently healthy cows must be employed to accurately assess the effects of periparturient inflammation on milk production.

One approach to assessing the effects of inflammation during the transition period is to block endogenous inflammation through the use of nonsteroidal antiinflammatory drugs (NSAID). Nonsteroidal antiinflammatory drugs are classified into 5 broad categories with slightly different modes of action (Gallo et al., 2008). Salicylate, a long-studied compound found in willow bark, is a weak inhibitor of cyclo-oxygenase (COX)-1 and COX-2 (Mitchell et al., 1993), and its probable mode of action is impairing the activation of nuclear factor $\kappa \mathrm{B}$, a common mediator of inflammation (Kopp and Ghosh, 1994; Pierce et al., 1996). This mode of action is not shared by all NSAID. Most NSAID are COX inhibitors, and neither genetic ablation nor pharmacological inhibition of COX enzymes replicated the beneficial metabolic responses induced by salicylates in mice (Yuan et al., 2001). If metabolic inflammation in transition dairy cows has a similar molecular architecture to the inflammation that occurs in rodent models of obesity, then COX inhibitors may have less potential to alter transition cow physiology than salicylate-class compounds.

Based partly on responses to exogenous cytokine administration (Bradford et al., 2009), we hypothesized that elevated plasma concentrations of NEFA and cytokines in early lactation cause an inflammatory response in the liver of transition dairy cows, resulting in partitioning of fatty acids toward triglyceride synthesis, depressed gluconeogenesis, and continued adipose tissue mobilization. This metabolic scenario could limit nutrient supply to the mammary gland, decreasing milk yield during peak lactation and affecting whole-lactation productivity. Therefore, we further hypothesized that the antiinflammatory effects of sa- licylate could improve metabolic function and enhance productivity. The specific objective of this study was to determine the effects of sodium salicylate (SS) treatment in the first week of lactation on production and health through the entire lactation.

\section{MATERIALS AND METHODS}

All experimental procedures were approved by the Kansas State University Institutional Animal Care and Use Committee. The experimental design, treatments, and sampling protocols have been previously described in a companion paper (Farney et al., 2013).

\section{Design and Treatments}

A total of 78 cows $[\mathrm{n}=39$ primiparous $(\mathbf{1 P}), \mathrm{n}=24$ second parity $(\mathbf{2 P})$, and $n=15$ third and greater parity $(\mathbf{3 P})$ ] from the Kansas State University Dairy Teaching and Research Facility (Manhattan) were blocked by parity and alternately assigned to treatment at parturition. Cows that were enrolled were apparently healthy, had a dystocia score $<2$ (1 to 5 scale), and were not visibly lame. Treatments consisted of administration of sodium salicylate $(1.95 \mathrm{~g} / \mathrm{L})$ in a molasses carrier $(0.14 \mathrm{~g} / \mathrm{L})$ via individual water bowls for 7 d postpartum. Control cows received water with the same molasses concentration for $7 \mathrm{~d}(\mathbf{C O N})$. Neither water nor DM intake was affected by treatment during the 7-d treatment period (Farney et al., 2013). On d 8 postpartum, all cows were given untreated water for the remainder of the experiment. Cows were housed in a tiestall facility in randomly assigned stalls through $\mathrm{d}$ 21 postpartum. Cattle were milked 3 times daily (0200, 1000, and $1800 \mathrm{~h}$ ) and fed ad libitum twice daily (0630 and $1800 \mathrm{~h}$ ) with a diet formulated to meet all nutrient requirements (Table 1). Feed and water intakes and milk yield were recorded daily during the first $21 \mathrm{~d}$ of lactation. After cows were removed from the tiestall facility (d 22 postpartum), they were returned to the general herd freestall facility, managed similarly, and received the same diet that they consumed while in the tiestall facility.

\section{Disease Incidence}

Cows were assessed daily for health status by trained personnel, including daily recording of rectal temperature and urine ketones (ReliOn ketone test strips, Bayer Healthcare LLC, Mishawaka, IN). Ketosis was defined as the detection of urine acetoacetate concentrations exceeding $80 \mathrm{mg} / \mathrm{dL}$ on any one day, or exceeding $40 \mathrm{mg} / \mathrm{dL}$ for 2 consecutive days to reduce the risk of false-positive responses at the lower threshold 
Table 1. Diet composition

\begin{tabular}{lc}
\hline Diet composition & Value \\
\hline Ingredient (\% of DM) & \\
Corn silage & 22.2 \\
WCGF $^{1}$ & 30.3 \\
Alfalfa hay & 20.4 \\
Cottonseed & 4.9 \\
Corn grain & 9.2 \\
Sorghum grain & 4.0 \\
Micronutrient premix & \\
Nutrient $\%$ of DM) & 9.0 \\
DM (\% as fed) & \\
CP & 53.2 \\
ADF & 18.6 \\
NDF & 18.0 \\
NFC & 30.5 \\
Ether extract & 38.1 \\
Ash & 5.2 \\
NE ${ }_{\mathrm{L}}^{3}$ (Mcal/kg) & 7.9 \\
\end{tabular}

${ }^{1}$ Wet corn gluten feed (Sweet Bran; Cargill Inc., Blair, NE).

${ }^{2}$ Premix consisted of $54.9 \%$ expeller soybean meal (SoyBest, Grain States Soya, West Point, NE), $14.3 \%$ limestone, $1.6 \%$ salt, $10.2 \%$ sodium bicarbonate, $2.0 \%$ magnesium oxide, $0.6 \%$ 4-Plex (Zinpro, Eden Prairie, MN), $0.3 \%$ selenium premix $(0.06 \%), 0.10 \%$ vitamin A and $\mathrm{D}$ premix, $1.6 \%$ vitamin E premix, $0.1 \%$ Rumensin 90 (Elanco Animal Health, Greenfield, IN), 2.6\% Diamond V XP (Diamond V, Cedar Rapids, IA), $10.0 \%$ Ca salts of long-chain fatty aicds (MegalacR, Arm \& Hammer Animal Nutrition, Princeton, NJ), 1.6\% potassium carbonate, and $0.1 \%$ Zinpro 100 (Zinpro).

${ }^{3}$ Estimated according to NRC (2001).

(LeBlanc, 2010). Metritis was identified as a cow that had a fever $\left(>39.4^{\circ} \mathrm{C}\right)$ and uterine discharge that was reddish brown and had an odor (Drillich et al., 2007). Cows that had a displaced abomasum during the trial were removed on the day of surgery. Clinical cases of mastitis were recorded as cows that had unusual milk consistency, as determined by trained milking personnel (Kelton et al., 1998), and were subsequently treated with an antibiotic. Disorders not described above were identified based on definitions provided by Kelton et al. (1998).

\section{Retrospective Analyses}

More than a year after all cows had completed treatments, herd management data and DHIA production records were used for a retrospective analysis of wholelactation production and risk of leaving the herd. Cows that did not remain in the herd for a subsequent calving were considered to have left the herd, and the reason entered in herd management software was recorded. Dairy employees who entered data and made culling decisions were blind to experimental treatments. Milk yield was recorded and milk samples collected during routine monthly herd DHIA testing. Milk samples were analyzed by Heart of America DHIA (Manhattan, KS) to determine concentrations of fat, true protein, and lactose (B-2000 Infrared Analyzer, Bentley Instru- ments, Chaska, MN). Predicted 305-d yields of milk, fat, and protein generated by DHIA (VanRaden, 1997) were used for all animals for which a value was generated. Predictions were not available for 3 animals that left the herd before 95 DIM.

\section{Statistical Analysis}

To test for randomization bias in milk production, treatment group differences in PTA for milk, fat, and protein yields were tested, and no significant differences between treatment groups were observed (all $P>0.50$ ). An additional potential confounding factor was the enrollment of 27 of the cows ( $\mathrm{n}=14$ control, $\mathrm{n}=13 \mathrm{SS}$ ) in a nutrition study following the completion of the 21-d salicylate study. The study (Vargas et al., 2012) was a Latin square design with treatments that failed to influence any measured outcome; therefore, the simple effect of enrollment in the study was included in the model. Statistical analysis of 305-d milk, fat, and protein yields was carried out by modeling the fixed effects of treatment, parity, treatment $\times$ parity interaction, and subsequent study enrollment. Additionally, the PTA for the variable of interest was included as a covariate to account for genetic contributions to variance.

Following analysis of 305-d data, test-day yield data for parity 3 cows were further investigated. Each testday yield value available from DHIA was assigned to a month of lactation, and data were analyzed using the Mixed Procedure of SAS (version 9.3, SAS Institute Inc., Cary, NC) to account for the fixed effects of treatment, month, and their interaction. Cow was modeled as a random effect, and repeated measures over time within cow were modeled with a spatial power covariance structure. Denominator degrees of freedom were estimated with the Kenward-Rogers method. One value was removed as an outlier in test-day fat yield analysis (Studentized residual $=4.2$ ).

Health disorder incidence was first assessed by binary logistic modeling to evaluate the effects of parity, treatment, and their interaction. If no parity $\times$ treatment interaction was observed in this analysis, all parities were grouped for risk analysis by Fisher's exact test; when parity $\times$ treatment interactions were detected, the analysis was also conducted for each parity group independently. Finally, survival curve analysis was used to assess treatment effects on time to leaving the herd. Failures represented death or culling for any reason, and cows that remained in the herd long enough to have a subsequent calf were censored. Differences in survival curves for the 2 treatment groups were assessed with the Wilcoxon $\chi^{2}$ test. All analyses other than the testday analysis were carried out using JMP (version 8.0; 
SAS Institute Inc.), and significance was declared at $P$ $\leq 0.05$ and tendencies at $0.05<P<0.10$.

\section{RESULTS}

As previously reported, SS administration resulted in therapeutic plasma salicylate concentrations (Farney et al., 2013). Plasma salicylate concentrations in treated cows on d 7 were $34.4 \pm 15.0 \mu \mathrm{g} / \mathrm{mL}$ (mean $\pm \mathrm{SD}$ ), with no differences detected between parities $(P=0.16)$.

\section{Milk Production}

We previously reported that SS treatment did not immediately affect milk production but significantly increased milk fat yield by wk 3 of lactation, after treatment ended (Farney et al., 2013). This result led us to investigate whole-lactation production responses to SS treatment.

Results of whole-lactation milk production analyses are shown in Figure 1. No overall treatment effect was observed $(P=0.16)$ on 305 -d milk yield, but we observed a highly significant treatment $\times$ parity interaction $(P<0.001)$. Salicylate administration increased $(P<0.01) 305$-d milk yield in $3 \mathrm{P}$ cows by $2,469 \pm$ 925 (standard error of the difference) $\mathrm{kg}$ (21\%; Figure $1 \mathrm{~A})$. In contrast, 305-d milk yield tended to decrease by $980 \pm 524 \mathrm{~kg}$ in $1 \mathrm{P}$ cows treated with SS $(8 \%, P=$ 0.07 ), and no treatment effect was observed in $2 \mathrm{P}$ cows. An overall treatment effect $(P<0.001)$ as well as a treatment $\times$ parity effect $(P<0.001)$ was observed for $305-\mathrm{d}$ milk fat yield. No treatment effects were detected in $1 \mathrm{P}$ or $2 \mathrm{P}$ cows, but $3 \mathrm{P}$ cows produced $130 \pm 29$ $\mathrm{kg}$ more fat over the lactation when treated with SS (30\% increase, $P<0.001$; Figure 3B). Finally, although no overall treatment effect was found for 305-d milk protein yield $(P=0.22)$, a tendency for a treatment $\times$ parity interaction was detected $(P=0.08)$. Again, no treatment effect was observed for $1 \mathrm{P}$ and $2 \mathrm{P}$ cows, but $3 \mathrm{P}$ cows tended to produce $49.0 \pm 25.8 \mathrm{~kg}$ more protein when treated with SS (14\% increase, $P=0.07$; Figure $3 \mathrm{C})$.

In an attempt to better understand the timing of the milk yield response observed in $3 \mathrm{P}$ cows, test-day records were subjected to repeated-measures analysis. Results, although not corrected for seasonal effects, were generally consistent with the responses in 305$\mathrm{d}$ variables (Figure 2$)$. Test-day milk $(P=0.08)$ and milk protein $(P=0.06)$ yields tended to be greater for SS than for CON, but no treatment $\times$ month interactions were observed for these variables. Test-day milk fat yield was significantly increased by SS $(P<0.01)$, and response tended to vary by month (interaction, $P$

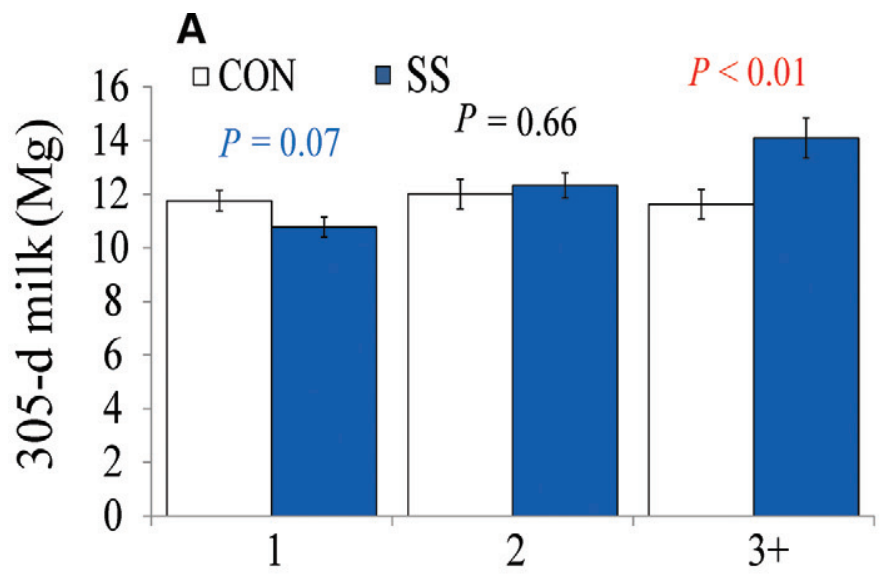

B
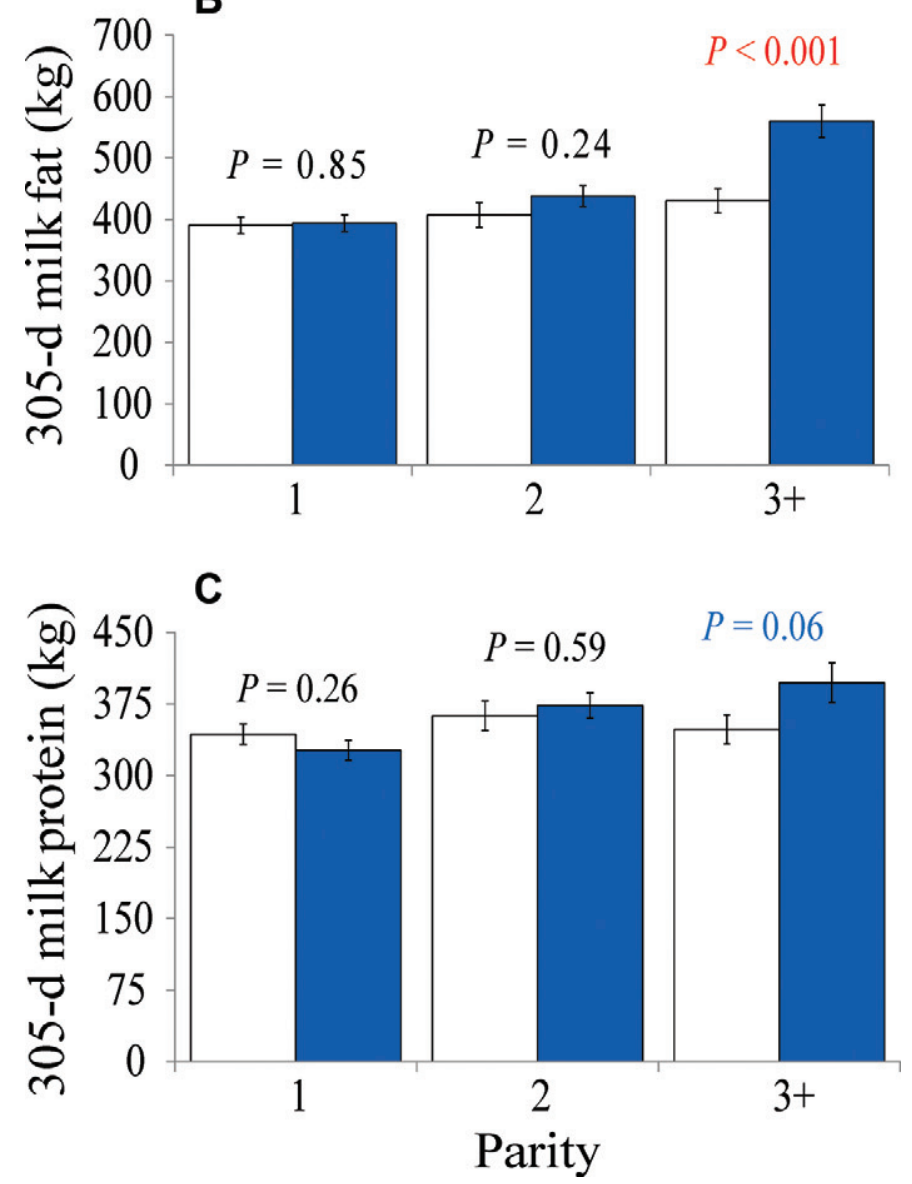

Figure 1. Whole-lactation data for cows treated during the first week of lactation with sodium salicylate (SS) or control (CON). Values are 305-d least squares means estimates \pm SEM derived from a model including PTA values and secondary study enrollment as additional fixed effects. (A) A treatment $\times$ parity interaction was observed $(P$ $<0.01)$ for 305-d milk yield, with third-parity SS cows having higher milk yield $(P<0.01)$, as well as a tendency $(P=0.07)$ for first-parity SS cows to have lower milk yield; (B) a treatment $\times$ parity effect $(P$ $<0.01$ ) was observed for 305-d milk fat yield; (C) 305-d milk protein yield had a tendency $(P=0.08)$ for a treatment $\times$ parity effect, and third-parity SS cows tended to have higher protein yield. Color version available in the online PDF. 

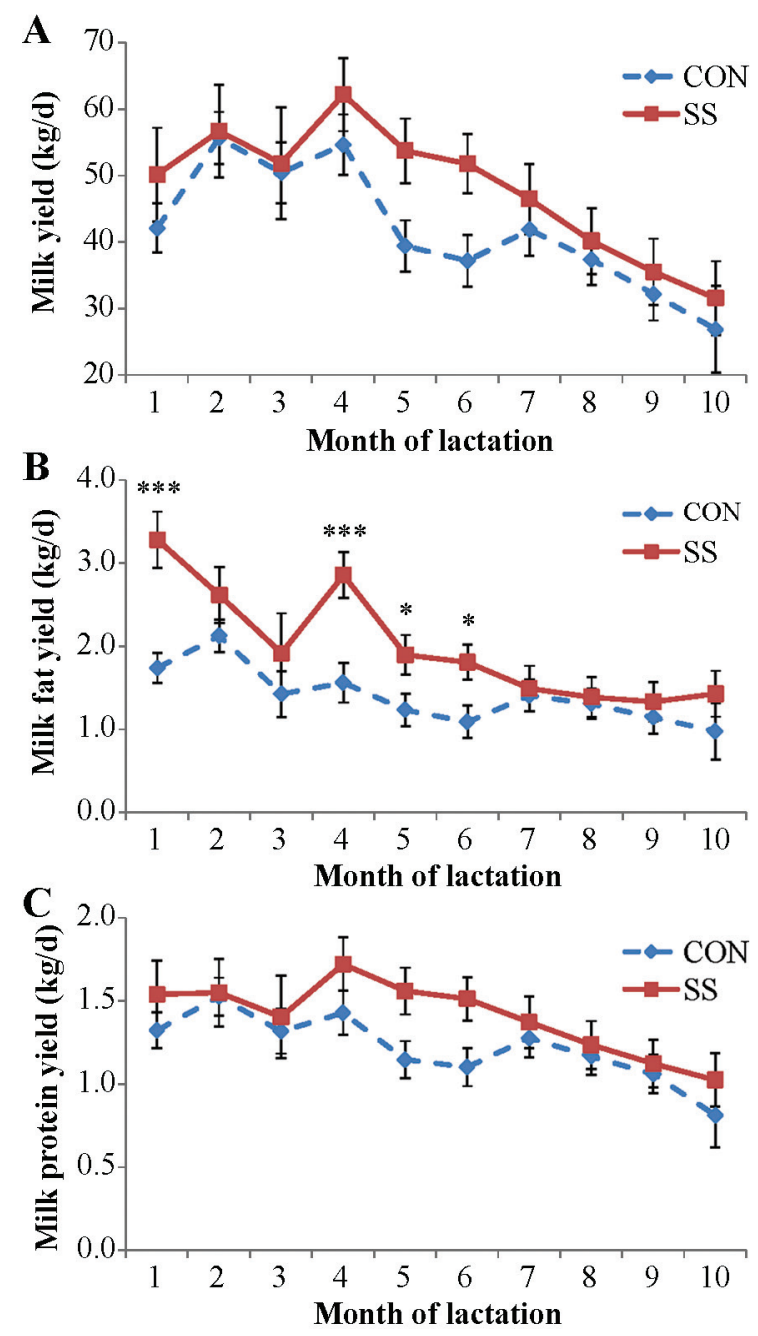

Figure 2. Test-day milk and component yields for third-parity cows treated during the first week of lactation with sodium salicylate (SS) or control (CON). Test-day values were assigned to month of lactation and repeated-measures analysis was conducted. Values are least squares means \pm SEM. (A) Treatment tended to alter test-day milk yield $(P=0.08)$, but no treatment by month interaction was detected $(P=0.85) ;(B)$ treatment altered test-day milk fat yield $(P<0.01)$ and we detected a tendency for a treatment by month interaction $(P=$ $0.08)$; $* * * P<0.001,{ }^{*} P<0.05$ for treatment contrasts at individual months; $(\mathrm{C})$ treatment tended to alter test-day milk protein yield $(P=$ $0.06)$, but no treatment by month interaction was detected $(P=0.84)$. Color version available in the online PDF.

$=0.08)$, with the greatest responses in mo 1 and 4 of lactation (Figure 2).

\section{Disease Incidence and Herd Retention}

Overall incidence rates of transition disorders and frequencies by treatment are shown in Table 2. Treatment did not significantly influence the incidence of any individual disorder in the first 21 DIM; however, a tendency for a treatment $\times$ parity interaction was detected for mastitis incidence $(P=0.07)$ and, within the 3P block, SS cows had a higher incidence of metritis than CON $(P=0.03$, Table 2$)$. We observed no differences in survival curves for initial disorder diagnosis (Wilcoxon $\chi^{2}$ test: $P=0.47$; data not shown) or for ketosis diagnosis (Wilcoxon $\chi^{2}$ test: $P=0.99$; data not shown) through 21 DIM, suggesting that differential onset of disease, or timing of disease treatment, did not bias treatment effects.

Herd retention until the subsequent lactation was evaluated by survival curve analysis (Figure 3 ), with no differences observed. A treatment $\times$ parity interaction was observed $(P=0.03)$, however, for overall risk of leaving the herd. Primiparous cows tended $(P<0.10)$ to have a greater risk of leaving the herd after SS treatment (Table 3), with no treatment effects in $2 \mathrm{P}$ and $3 \mathrm{P}$ cows. Analysis of risk for specific reasons for leaving the herd (Table 3) failed to identify significant treatment effects.

\section{DISCUSSION}

Standardized 305-d milk and milk fat yields were increased in $3 \mathrm{P}$ cows treated with SS for the first week of lactation. Although no treatment effects on milk yield were detected during the 7 -d treatment period, milk yields began diverging toward the end of the intensive 21-d monitoring period (Farney et al., 2013). Few studies have evaluated long-term responses to antiinflammatory treatment in dairy cattle, but our findings are not entirely without precedent. Bertoni et al. (2004) treated 11 cows/treatment with lysine acetyl-salicylate

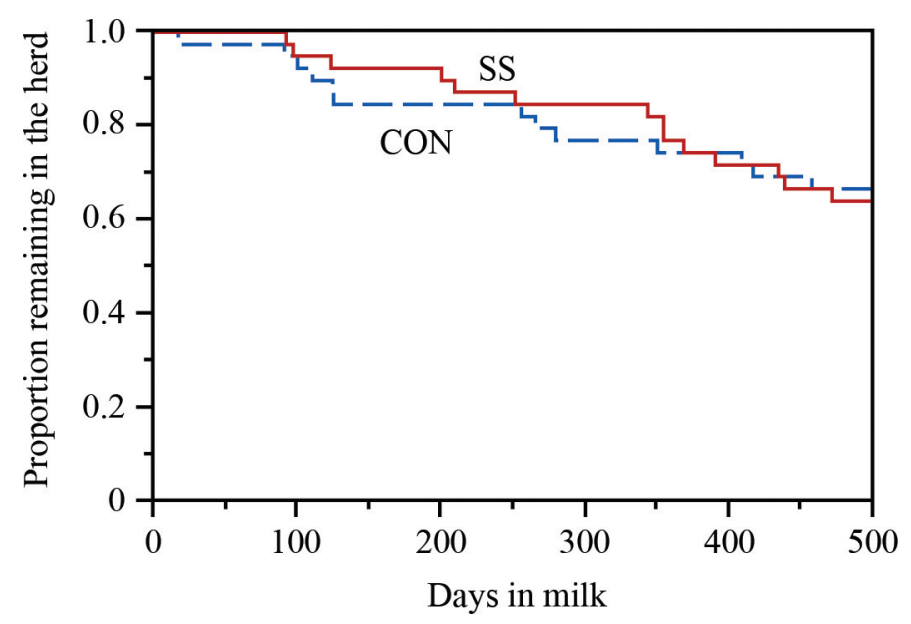

Figure 3. Herd retention for cows treated during the first week of lactation with sodium salicylate (SS; solid line) or control (CON; dashed line). Failures represent death or culling for any reason, and cows that remained in the herd long enough to have a subsequent calf were censored. The survival curves did not differ (Wilcoxon $\chi^{2}$ test: $P$ $=0.99)$. Color version available in the online PDF. 
Table 2. Incidence of health disorders (number per treatment; $\mathrm{n}=39$ cows per treatment) in the first 21 DIM

\begin{tabular}{|c|c|c|c|}
\hline \multirow[b]{2}{*}{ Disorder } & \multicolumn{2}{|c|}{ Treatment $^{1}$} & \multirow[b]{2}{*}{$P$-value } \\
\hline & $\mathrm{CON}$ & SS & \\
\hline Ketosis & 12 & 13 & NS \\
\hline Lameness & 3 & 1 & NS \\
\hline Temperature $^{2}$ & 11 & 11 & NS \\
\hline Metritis & 8 & 10 & $\mathrm{NS}^{3}$ \\
\hline Displaced abomasum & 2 & 4 & NS \\
\hline Diarrhea & 4 & 2 & NS \\
\hline Retained placenta & 4 & 4 & NS \\
\hline Mastitis & 7 & 8 & NS \\
\hline Other ${ }^{4}$ & 4 & 6 & NS \\
\hline Multiple ${ }^{5}$ & 16 & 19 & NS \\
\hline
\end{tabular}

${ }^{1}$ Treatment consisted of administration of sodium salicylate (SS; 1.95 $\mathrm{g} / \mathrm{L})$ in a molasses carrier $(0.14 \mathrm{~g} / \mathrm{L})$ via individual water bowls for $7 \mathrm{~d}$ postpartum; control $(\mathrm{CON})$ cows received water with the same molasses concentration for $7 \mathrm{~d}$.

${ }^{2}$ Cows had a fever $>39.4^{\circ} \mathrm{F}$ but no other symptoms.

${ }^{3}$ Parity $\times$ treatment interaction; treatment effect was significant for third-parity block (11 vs. $67 \%$ incidence for CON vs. SS, respectively; $P=0.03$ ).

${ }^{4}$ Cows that were diagnosed with something other than that listed above (e.g., hardware disease).

${ }^{5}$ Cows that were diagnosed with more than one disorder.

(aspirin) or placebo for the first $5 \mathrm{~d}$ postpartum and then monitored milk production through d 126 of lactation. Despite the small sample size of that initial study, the researchers found that peak milk yield tended to increase with aspirin treatment $(P<0.10)$. The same group subsequently conducted a similar study with 23 cows/treatment and found that aspirin treatment over the first $5 \mathrm{~d}$ of lactation increased milk yield through $\mathrm{d}$ 60 of lactation $(P<0.05)$, with a $13 \%$ increase in peak milk yield (Trevisi and Bertoni, 2008).

Two other studies have evaluated responses to flunixin meglumine early in the postpartum period. Administration of flunixin meglumine (i.v.) for the first $3 \mathrm{~d}$ after parturition had no effect on milk yield, $3.5 \%$ FCM yield, ECM yield, or milk fat, protein, and lactose percentages in early lactation (Shwartz et al., 2009). A similar study evaluated responses to i.v. flunixin meglumine given 2 and $24 \mathrm{~h}$ postpartum, and likewise found no benefit for early milk production (Duffield et al., 2009).

In addition to these few studies in which NSAID were administered to all postpartum cows, others have evaluated their effects on cows treated for mastitis. In an endotoxin-induced mastitis model, SS slowed the return to prechallenge milk production levels (Morkoc et al., 1993). The quantity of SS administered to these cows daily was much greater than in the current study (plasma salicylate concentrations of 236 vs. $34 \pm 15.0 \mu \mathrm{g} /$ $\mathrm{mL}$ in this study), and the negative production effects may have been related to the high dose of SS. However, flunixin meglumine also decreased milk production in an endotoxin-induced mastitis model (Anderson et al., 1986) and, in another study, failed to significantly alter milk yield over $6 \mathrm{~d}$ when administered (following ceftiofur treatment) to cows diagnosed with metritis in early lactation (Drillich et al., 2007). When flunixin meglumine was administered to cows with toxic mastitis, no differences in milk production were observed in the 10 wk following the development of mastitis (Dascanio et al., 1995). Taken together, responses to salicylates appear to differ from responses to other classes of NSAID when administered in early lactation and seem to have different effects than NSAID treatment in conjunction with mastitis treatment. These apparent differences may also be caused by differences in study design, including timing of NSAID administration, length of treatment, and, critically, the evaluation period after treatment.

These findings raise several intriguing questions. One is the reason for the delayed response to SS treatment. Although treatments began to diverge by 21 DIM, no effects were observed during treatment, which is consistent with the lack of milk response to NSAID treatment in the many short-term studies discussed above. Results

Table 3. Reasons cows left herd ${ }^{1}$

\begin{tabular}{|c|c|c|c|c|c|c|c|}
\hline \multirow[b]{2}{*}{ Reason } & \multicolumn{2}{|c|}{ First parity } & \multicolumn{2}{|c|}{ Second parity } & \multicolumn{2}{|c|}{ Third parity } & \multirow[b]{2}{*}{ Total } \\
\hline & $\mathrm{CON}$ & SS & $\mathrm{CON}$ & SS & $\mathrm{CON}$ & SS & \\
\hline Foot/leg & - & - & - & - & 1 & - & 1 \\
\hline Low production & - & 1 & 1 & - & - & - & 2 \\
\hline Reproduction & 1 & 3 & 1 & 2 & 1 & 1 & 9 \\
\hline Injury & - & - & - & - & - & 1 & 1 \\
\hline Died & - & - & 1 & 1 & 1 & - & 3 \\
\hline Mastitis & - & 2 & 2 & 2 & 1 & - & 7 \\
\hline Udder & - & - & 1 & - & - & - & 1 \\
\hline Total & 1 & 6 & 6 & 5 & 4 & 2 & 24 \\
\hline
\end{tabular}

${ }^{1}$ All values are numbers of cows based on parity and treatment for each specific reason cows were removed from the herd. The SS cows received sodium salicylate $(1.95 \mathrm{~g} / \mathrm{L})$ in a molasses carrier $(0.14 \mathrm{~g} / \mathrm{L})$ via individual water bowls for $7 \mathrm{~d}$ postpartum; control (CON) cows received water with the same molasses concentration for $7 \mathrm{~d}$. 
of test-day yield analysis likewise showed that milk yield differences between treatments may have been greatest in mo 4 to 6 of lactation (Figure 2). Although this analysis is imprecise because test-day yields were not corrected for seasonal effects and because of the small number of cows involved, the test-day results were consistent with estimated 305-d yields. Even ignoring the test-day results, SS must have affected milk yield for the majority of the lactation. To increase $305-\mathrm{d}$ milk yield by almost $2,500 \mathrm{~kg}$ in $3 \mathrm{P}$ cows, the mean daily response would have to average more than $8 \mathrm{~kg} / \mathrm{d}$.

These production responses to SS were not likely a result of altered metabolic function. In contrast to our original hypothesis that SS would improve liver function and decrease adipose tissue catabolism, SS-treated cows displayed decreased plasma glucose and increased plasma NEFA and BHBA concentrations in early lactation (Farney et al., 2013), metabolic profiles more commonly associated with impaired lactation performance in mature cows (Ospina et al., 2010). This disconnect between metabolic indicators and productivity was surprising, but there is at least one precedent for this observation: aspirin injections over the first $5 \mathrm{~d}$ of lactation decreased plasma glucose and increased plasma NEFA concentration but increased peak milk yield a month later (Bertoni et al., 2004).

In addition to the evidence that antiinflammatory treatment can promote a sustained increase in milk production, a large body of work details the central role of inflammatory signals in mammary gland development, lactogenesis, galactopoiesis, and involution (Vorbach et al., 2006; Nørgaard et al., 2008; Watson, 2009). Although inflammatory mediators are critical for prepartum mammary development (Cao et al., 2001), these same signals can suppress milk synthesis during lactation; for example, nuclear factor- $\kappa \mathrm{B}$ activation is associated with impaired responses to prolactin and decreased $\beta$-casein production (Beaton et al., 2003). Abiotic (sterile) inflammation induced by endotoxin can cause dramatic impairment of pathways driving synthesis of nearly all milk components. Endotoxin significantly decreases transcript abundance of glucose transporters, fatty acid binding protein 3 , and carnitine transporters in rat mammary tissue (Ling and Alcorn, 2010) and induced similar suppression of transcripts for fatty acid synthesis proteins, potassium channels, and carbohydrate metabolism enzymes in mouse mammary tissue (Zheng et al., 2006). The net effect of inflammatory downregulation of nutrient transporters and synthetic enzymes (and probably other undiscovered mechanisms) is that secretion of all major milk components is suppressed by the severe inflammation induced by endotoxin in the dairy cow (Oliver and Calvinho, 1995; Ballou, 2012). We propose that the sustained ef- fect of SS treatment during the critical first week of lactation may be due to inhibition of inflammatory pathways in the mammary epithelium. If inflammatory signals have a particularly large effect on mammary lipogenic pathways, then this proposed mode of action may also help explain the dramatic effect of SS on milk fat yield, although we are unaware of any data to support this hypothesis.

Another intriguing aspect of our results was the finding that only $3 \mathrm{P}$ cows increased milk production when treated with SS. Some evidence indicates that multiparity increases inflammatory pressure. In mice, multiparous dams have elevated inflammatory mediators in several organs compared with primiparous dams (Rebholz et al., 2012). One relevant factor is that older cows are more likely to suffer from subclinical mastitis; a recent study reported a 3 -fold higher risk of elevated milk somatic cells for multiparous cows compared with primiparous herdmates (van Straten et al., 2009). Furthermore, a recent report demonstrated that flunixin meglumine treatment attenuated the decline in milk production following Escherichia coli-induced mastitis in multiparous cows, but not primiparous cows (Yeiser et al., 2012). Finally, sows injected with the NSAID meloxicam after parturition showed parity-dependent responses, with meloxicam increasing the growth rate of low-BW piglets only for multiparous sows (Mainau et al., 2012).

We are unaware of prior evidence in the literature that NSAID treatment might impair the milk production capacity of primiparous dams. However, it is known that mammary development (epithelial hyperplasia) continues in early lactation of primiparous cows to a far greater extent than in multiparous cows (Miller et al., 2006). Although it has not been directly studied, these findings and differences in the lactation curves of primiparous and multiparous cows indicate that cell proliferation may dominate in early-lactation primiparous cows, and cell death may begin to dominate much earlier in lactation of multiparous cows (Capuco et al., 2003). Given that inflammatory mediators intersect with both proliferative and apoptotic pathways, such differences in the status of mammary cell dynamics in cows of different parities may dramatically alter responses to suppression of inflammation.

Administration of SS did not alter the incidence of health disorders during the first 21 DIM, except that older cows treated with SS had a greater incidence of metritis. It should be noted that this study had limited power to detect differences in production disease incidence. Nevertheless, previous work with even more limited animal numbers showed an increase in metritis incidence (30 vs. $14 \%$ for control) in transition dairy cows given daily injections of aspirin (Trevisi and Ber- 
toni, 2008). Furthermore, 2 recent studies found that flunixin meglumine administration negatively affected health in early lactation, as reflected in increased rectal temperatures, suppression of DMI (Shwartz et al., 2009), and increased incidence of both retained placenta and metritis (Duffield et al., 2009). These increased risks are likely a consequence of suppressed inflammatory signaling in the immune system. Inflammatory signals such as cytokines are essential to activate and attract leukocytes, especially neutrophils, which are critical for rapid clearance of pathogens to avoid overt disease (Kolaczkowska and Kubes, 2013).

Another interesting observation was a greater risk of removal of $1 \mathrm{P}$ cows from the herd if they were given SS during the first week of lactation. There was no consistent reason why these cows were culled, although the most common reasons for leaving the herd were reproductive issues and chronic mastitis. Suppression of prostaglandin synthesis has been reported to alter postpartum reproductive traits in Brown Swiss cows (Guilbault et al., 1987). A prostaglandin synthase inhibitor administered to cows twice daily for $6 \mathrm{~d}$ postpartum reduced ovarian activity and altered progesterone waves after calving. Prostaglandin $\mathrm{F}_{2 \alpha}$ can decrease the postpartum return-to-estrus interval and increase ovarian follicle size (Tolleson and Randel, 1988; Villeneuve et al., 1988; White and Dobson, 1990). One previous study found aspirin administration to impair fertility in Brahman cows (Stahringer et al., 1999). The aspirintreated cows had lower pregnancy rates, more abnormal estrous cycles, and reduced formation of corpora lutea after estrus. Primiparous aspirin-treated cows had a longer postpartum return-to-estrus interval, providing further evidence of detrimental effects of aspirin administration on postpartum reproduction (Stahringer et al., 1999). In contrast, Bertoni et al. (2004) used only multiparous cows and reported numerically increased the first-service conception rate (50 vs. $27 \%$ ) in aspirintreated cows. Treatment with the NSAID carprofen likewise increased pregnancy rates, specifically in cows with subclinical endometritis (Priest et al., 2013). As for disease outcomes, antiinflammatory treatment can likely either support or impair fertility, depending on the context of its use and the timing of treatment relative to parturition.

It is important to note that salicylates are not currently approved for use in dairy cattle for the purpose of enhancing productivity; in fact, their use as antipyretic or analgesic agents is not formally approved (USP, 2004). Even for off-label use, the Food Animal Residue Avoidance Databank recommends a 24-h milk withdrawal after aspirin administration (Damian et al., 1997). Further work will be required to document the effect of salicylates on animal health and product safety before these findings can be broadly applied.

\section{CONCLUSIONS}

Sodium salicylate administered in drinking water during the first $7 \mathrm{~d}$ of lactation increased whole-lactation milk production in mature cows (parity $3+$ ) despite the lack of a milk production response during treatment and negative effects on metabolic markers. Treatment of cows with SS did not significantly alter the overall incidence of health disorders. However, primiparous cows tended to have an increased risk of leaving the herd after SS treatment. Further research into potential modes of action for this response, including alterations in mammary gland programming, may help clarify the results observed in this study. Antiinflammatory interventions considered for transition dairy cows need to be weighed against possible negative effects on immune and reproductive function.

\section{ACKNOWLEDGMENTS}

This article is Contribution no. 13-353-J from the Kansas Agricultural Experiment Station. This project was supported by the National Research Initiative (Grant no. 2009-35206-05271) from the US Department of Agriculture National Institute of Food and Agriculture (Washington, DC). The authors express their appreciation to Mike Scheffel, Chad Mullins, and Kansas State University graduate and undergraduate students (Manhattan) for help in sample collection and analysis. We gratefully acknowledge the donation of molasses from Quality Liquid Feeds (Dodgeville, WI).

\section{REFERENCES}

Anderson, K. L., A. R. Smith, R. D. Shanks, L. E. Davis, and B. K. Gustafsson. 1986. Efficacy of flunixin meglumine for the treatment of endotoxin-induced bovine mastitis. Am. J. Vet. Res. 47:13661372 .

Ballou, M. A. 2012. Growth and Development Symposium: Inflammation: Role in the etiology and pathophysiology of clinical mastitis in dairy cows. J. Anim. Sci. 90:1466-1478.

Beaton, A., M. K. Broadhurst, R. J. Wilkins, and T. T. Wheeler. 2003. Suppression of beta-casein gene expression by inhibition of protein synthesis in mouse mammary epithelial cells is associated with stimulation of NF-kappaB activity and blockage of prolactin-Stat5 signaling. Cell Tissue Res. 311:207-215.

Bertoni, G., E. Trevisi, X. Han, and M. Bionaz. 2008. Effects of inflammatory conditions on liver activity in puerperium period and consequences for performance in dairy cows. J. Dairy Sci. 91:3300-3310.

Bertoni, G., E. Trevisi, and F. Piccioli-Cappelli. 2004. Effects of acetyl-salicylate used in post-calving of dairy cows. Vet. Res. Commun. 28:217-219.

Bionaz, M., E. Trevisi, L. Calamari, F. Librandi, A. Ferrari, and G. Bertoni. 2007. Plasma paraoxonase, health, inflammatory condi- 
tions, and liver function in transition dairy cows. J. Dairy Sci. 90:1740-1750.

Bradford, B. J., L. K. Mamedova, J. E. Minton, J. S. Drouillard, and B. J. Johnson. 2009. Daily injection of tumor necrosis factor- $\alpha$ increases hepatic triglycerides and alters transcript abundance of metabolic genes in lactating dairy cattle. J. Nutr. 139:1451-1456.

Cao, Y., G. Bonizzi, T. N. Seagroves, F. R. Greten, R. Johnson, E. V. Schmidt, and M. Karin. 2001. IKK $\alpha$ provides an essential link between RANK signaling and cyclin D1 expression during mammary gland development. Cell 107:763-775.

Capuco, A. V., S. E. Ellis, S. A. Hale, E. Long, R. A. Erdman, X. Zhao, and M. J. Paape. 2003. Lactation persistency: Insights from mammary cell proliferation studies. J. Anim. Sci. 81:18-31.

Damian, P., A. L. Craigmill, and J. E. Riviere. 1997. Extralabel use of nonsteroidal anti-inflammatory drugs. J. Am. Vet. Med. Assoc. 211:860-861.

Dascanio, J. J., G. D. Mechor, Y. T. Grohn, D. G. Kenney, C. A. Booker, P. Thompson, C. L. Chiffelle, J. M. M. Musser, and L. D. Warnick. 1995. Effect of phenylbutazone and flunixin meglumine on acute toxic mastitis in dairy cows. Am. J. Vet. Res. 56:1213-1218.

Drillich, M., D. Voigt, D. Forderung, and W. Heuwieser. 2007. Treatment of acute puerperal metritis with flunixin meglumine in addition to antibiotic treatment. J. Dairy Sci. 90:3758-3763.

Duffield, T. F., H. Putnam-Dingwell, D. Weary, A. Skidmore, L. Neuder, W. Raphael, S. Millman, N. Newby, and K. E. Leslie. 2009. Effect of flunixin meglumine treatment following parturition on cow health and milk production. J. Dairy Sci. 92(E-Suppl. 1):117. (Abstr.)

Farney, J. K., L. K. Mamedova, J. F. Coetzee, B. KuKanich, L. M. Sordillo, S. K. Stoakes, J. E. Minton, L. C. Hollis, and B. J. Bradford. 2013. Anti-inflammatory salicylate treatment alters the metabolic adaptations to lactation in dairy cattle. Am. J. Physiol. Regul. Integr. Comp. Physiol. 305:R110-R117.

Gallo, P., S. Fabbrocino, F. Vinci, M. Fiori, V. Danese, and L. Serpe. 2008. Confirmatory identification of sixteen non-steroidal antiinflammatory drug residues in raw milk by liquid chromatography coupled with ion trap mass spectrometry. Rapid Commun. Mass Spectrom. 22:841-854.

Graugnard, D. E., M. Bionaz, E. Trevisi, K. M. Moyes, J. L. SalakJohnson, R. L. Wallace, J. K. Drackley, G. Bertoni, and J. J. Loor. 2012. Blood immunometabolic indices and polymorphonuclear neutrophil function in peripartum dairy cows are altered by level of dietary energy prepartum. J. Dairy Sci. 95:1749-1758.

Guilbault, L. A., W. W. Thatcher, and C. J. Wilcox. 1987. Influence of a physiological infusion of prostaglandin $\mathrm{F}_{2 \alpha}$ into postpartum cows with partially suppressed endogenous production of prostaglandins. 2. Interrelationships of hormonal, ovarian and uterine responses. Theriogenology 27:947-957.

Humblet, M.-F., H. Guyot, B. Boudry, F. Mbayahi, C. Hanzen, F. Rollin, and J.-M. Godeau. 2006. Relationship between haptoglobin, serum amyloid A, and clinical status in a survey of dairy herds during a 6-month period. Vet. Clin. Pathol. 35:188-193.

Huzzey, J. M., T. F. Duffield, S. J. LeBlanc, D. M. Veira, D. M. Weary, and M. A. G. von Keyserlingk. 2009. Short communication: Haptoglobin as an early indicator of metritis. J. Dairy Sci. 92:621-625.

Ingvartsen, K. L. 2006. Feeding- and management-related diseases in the transition cow: Physiological adaptations around calving and strategies to reduce feeding-related diseases. Anim. Feed Sci. Technol. 126:175-213.

Kelton, D. F., K. D. Lissemore, and G. Martin. 1998. Recommendations for recording and calculating the incidence of selected clinical diseases of dairy cattle. J. Dairy Sci. 81:2502-2509.

Kolaczkowska, E., and P. Kubes. 2013. Neutrophil recruitment and function in health and inflammation. Nat. Rev. Immunol. 13:159175 .

Kopp, E., and S. Ghosh. 1994. Inhibition of NF-kB by sodium salicylate and aspirin. Science 265:956-959.

LeBlanc, S. 2010. Monitoring metabolic health of dairy cattle in the transition period. J. Reprod. Dev. 56:S29-S35.
Ling, B., and J. Alcorn. 2010. LPS-induced inflammation downregulates mammary gland glucose, fatty acid, and L-carnitine transporter expression at different lactation stages. Res. Vet. Sci. 89:200-202.

Mainau, E., J. L. Ruiz-de-la-Torre, A. Dalmau, J. M. Salleras, and X. Manteca. 2012. Effects of meloxicam (Metacam ${ }^{\circledR}$ ) on post-farrowing sow behaviour and piglet performance. Animal 6:494-501.

Miller, N., L. Delbecchi, D. Petitclerc, G. F. Wagner, B. G. Talbot, and P. Lacasse. 2006. Effect of stage of lactation and parity on mammary gland cell renewal. J. Dairy Sci. 89:4669-4677.

Mitchell, J. A., P. Akarasereenont, C. Thiemermann, R. J. Flower, and J. R. Vane. 1993. Selectivity of nonsteroidal antiinflammatory drugs as inhibitors of constitutive and inducible cyclooxygenase. Proc. Natl. Acad. Sci. USA 90:11693-11697.

Morkoc, A. C., W. L. Hurley, H. L. Whitmore, and B. K. Gustafsson. 1993. Bovine acute mastitis: Effects of intravenous sodium salicylate on endotoxin-induced intramammary inflammation. J. Dairy Sci. 76:2579-2588

Mullins, C. R., L. K. Mamedova, M. J. Brouk, C. E. Moore, H. B. Green, K. L. Perfield, J. F. Smith, J. P. Harner, and B. J. Bradford. 2012. Effects of monensin on metabolic parameters, feeding behavior, and productivity of transition dairy cows. J. Dairy Sci. 95:1323-1336.

Nørgaard, J. V., P. K. Theil, M. T. Sørensen, and K. Sejrsen. 2008. Cellular mechanisms in regulating mammary cell turnover during lactation and dry period in dairy cows. J. Dairy Sci. 91:23192327.

NRC. 2001. Nutrient Requirements of Dairy Cattle. 7th rev. ed. Natl. Acad. Press, Washington, DC.

Oliver, S. P., and L. F. Calvinho. 1995. Influence of inflammation on mammary gland metabolism and milk composition. J. Anim. Sci. $73: 18-33$

Ospina, P. A., D. V. Nydam, T. Stokol, and T. R. Overton. 2010. Associations of elevated nonesterified fatty acids and $\beta$-hydroxybutyrate concentrations with early lactation reproductive performance and milk production in transition dairy cattle in the northeastern United States. J. Dairy Sci. 93:1596-1603.

Pierce, J. W., M. A. Read, H. Ding, F. W. Luscinskas, and T. Collins.

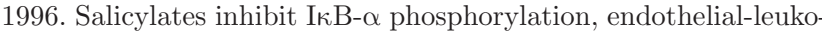
cyte adhesion molecule expression, and neutrophil transmigration. J. Immunol. 156:3961-3969.

Priest, N. V., S. McDougall, C. R. Burke, J. R. Roche, M. Mitchell, K. L. McLeod, S. L. Greenwood, and S. Meier. 2013. The responsiveness of subclinical endometritis to a nonsteroidal antiinflammatory drug in pasture-grazed dairy cows. J. Dairy Sci. 96:4323-4332. http://dx.doi.org/10.3168/jds.2012-6266.

Rebholz, S. L., T. Jones, K. T. Burke, A. Jaeschke, P. Tso, D. A D'Alessio, and L. A. Woollett. 2012. Multiparity leads to obesity and inflammation in mothers and obesity in male offspring. Am. J. Physiol. Endocrinol. Metab. 302:E449-E457.

Shwartz, G., K. L. Hill, M. J. VanBaale, and L. H. Baumgard. 2009. Effects of flunixin meglumine on pyrexia and bioenergetic variables in postparturient dairy cows. J. Dairy Sci. 92:1963-1970.

Stahringer, R. C.. D. A. Neuendorff, and R. D. Randel. 1999. The effect of aspirin administration and parity on plasma salicylate concentrations and postpartum reproductive parameters in Brahman cows. Prostaglandins 58:125-138.

Tolleson, D. R., and R. D. Randel. 1988. Effects of alfaprostol and uterine palpation on postpartum interval and pregnancy rate to embryo transfer in Brahman influenced beef-cows. Theriogenology 29:555-564.

Trevisi, E., and G. Bertoni. 2008. Attenuation with acetylsalicylate treatments of inflammatory conditions in periparturient dairy cows. Pages 22-37 in Aspirin and Health Research Progress. P. I. Quinn, ed. Nova Science Publishers, Hauppauge, NY.

USP. 2004. Veterinary pharmaceutical information monographs-Anti-inflammatories. J. Vet. Pharmacol. Ther. 27:6-14.

van Straten, M., M. Friger, and N. Y. Shpigel. 2009. Events of elevated somatic cell counts in high-producing dairy cows are as- 
sociated with daily body weight loss in early lactation. J. Dairy Sci. 92:4386-4394.

VanRaden, P. M. 1997. Lactation yields and accuracies computed from test day yields and (co)variances by best prediction. J. Dairy Sci. 80:3015-3022.

Vargas, C. F., M. Engstrom, and B. J. Bradford. 2012. Effects of dietary amylase and sucrose on productivity of cows fed low-starch diets. J. Dairy Sci. 95(Suppl. 2):116. (Abstr.)

Villeneuve, P., J. J. Dufour, and L. A. Guilbault. 1988. Influence of infusion of prostaglandin $\mathrm{F}_{2 \alpha}\left(\mathrm{PGF}_{2 \alpha}\right)$ and weaning on surface and histologic population of ovarian follicles in postpartum beef-cows. J. Anim. Sci. 66:3174-3184.

Vorbach, C., M. R. Capecchi, and J. M. Penninger. 2006. Evolution of the mammary gland from the innate immune system? Bioessays 28:606-616.
Watson, C. J. 2009. Immune cell regulators in mouse mammary development and involution. J. Anim. Sci. 87:35-42.

White, A. J., and H. Dobson. 1990. Effect of prostaglandin- $\mathrm{F}_{2 \alpha}$ on the fertility of dairy-cows after calving. Vet. Rec. 127:588-592.

Yeiser, E. E., K. E. Leslie, M. L. McGilliard, and C. S. Petersson-Wolfe. 2012. The effects of experimentally induced Escherichia coli mastitis and flunixin meglumine administration on activity measures, feed intake, and milk parameters. J. Dairy Sci. 95:4939-4949.

Yuan, M., N. Konstantopoulos, J. Lee, L. Hansen, Z.-W. Li, M. Karin, and S. E. Shoelson. 2001. Reversal of obesity- and diet-induced insulin resistance with salicylates or targeted disruption of Ikkbeta. Science 293:1673-1677.

Zheng, J., A. Watson, and D. Kerr. 2006. Genome-wide expression analysis of lipopolysaccharide-induced mastitis in a mouse model. Infect. Immun. 74:1907-1915. 